\title{
Characterization and complete genome sequence of Privateer, a highly prolate Proteus mirabilis podophage
}

\author{
James E Corban ${ }^{1,2,3}$, Jolene Ramsey ${ }^{\text {Corresp. 1, } 2}$ \\ ${ }^{1}$ Department of Biochemistry \& Biophysics, Texas A\&M University, College Station, Texas, United States \\ 2 Center for Phage Technology, Texas A\&M University, College Station, Texas, United States \\ 3 Department of Biochemistry, University of Wisconsin-Madison, Madison, Wisconsin, United States \\ Corresponding Author: Jolene Ramsey \\ Email address: jolenerr@tamu.edu
}

The Gram-negative bacterium Proteus mirabilis causes a large proportion of catheterassociated urinary tract infections, which are among the world's most common nosocomial infections. Here, we characterize $P$. mirabilis bacteriophage Privateer, a prolate podophage of the C3 morphotype isolated from Texas wastewater treatment plant activated sludge. Basic characterization assays demonstrated Privateer has a latent period of $~ 40$ minutes and average burst size around 140. In the $90.7 \mathrm{~kb}$ Privateer genome, 43 functions were assigned for the 144 predicted protein-coding genes. Genes encoding DNA replication proteins, DNA modification proteins, four tRNAs, lysis proteins, and structural proteins were identified. Cesium-gradient purified Privateer particles analyzed via LC-MS/MS verified the presence of several predicted structural proteins, including a longer, minor capsid protein apparently produced by translational frameshift. Comparative analysis demonstrated Privateer shares $83 \%$ nucleotide similarity with Cronobacter phage vB_CsaP_009, but low nucleotide similarity with other known phages. Predicted structural proteins in Privateer appear to have evolutionary relationships with other prolate podophages, in particular the Kuraviruses 
1 Characterization and complete genome sequence of Privateer, a highly prolate

2 Proteus mirabilis podophage

6 'Department of Biochemistry \& Biophysics, Texas A\&M University, College Station, Texas, 7 USA

$8 \quad{ }^{2}$ Center for Phage Technology, Texas A\&M University, College Station, Texas, USA

9 3Present address: Department of Biochemistry, University of Wisconsin-Madison, Madison,

10 Wisconsin, USA

Corresponding Author:

Jolene Ramsey

300 Olsen Blvd 2128 TAMU, College Station, Texas, 77843, USA

Email address: jolenerr@tamu.edu

\begin{abstract}
The Gram-negative bacterium Proteus mirabilis causes a large proportion of catheterassociated urinary tract infections, which are among the world's most common nosocomial infections. Here, we characterize $P$. mirabilis bacteriophage Privateer, a prolate podophage of the C3 morphotype isolated from Texas wastewater treatment plant activated sludge. Basic characterization assays demonstrated Privateer has a latent period of $\sim 40$ minutes and average burst size around 140. In the $90.7 \mathrm{~kb}$ Privateer genome, 43 functions were assigned for the 144 predicted protein-coding genes. Genes encoding DNA replication proteins, DNA modification proteins, four tRNAs, lysis proteins, and structural proteins were identified. Cesium-gradient purified Privateer particles analyzed via LC-MS/MS verified the presence of several predicted structural proteins, including a longer, minor capsid protein apparently produced by translational frameshift. Comparative analysis demonstrated Privateer shares $83 \%$ nucleotide similarity with Cronobacter phage vB_CsaP_009, but low nucleotide similarity with other known phages. Predicted structural proteins in Privateer appear to have evolutionary relationships with other prolate podophages, in particular the Kuraviruses.
\end{abstract}

\title{
Introduction
}

Proteus mirabilis, a ubiquitous Gram-negative bacterium, is most frequently isolated from the gastrointestinal tracts of humans and animals (O'Hara, Brenner \& Miller, 2000; Drzewiecka, 2016). Human infections with $P$. mirabilis often occur in the eyes, mouth, and intestines, yet are predominantly associated with urinary tract infections (UTIs) (Schaffer \& Pearson, 2015; Armbruster, Mobley \& Pearson, 2018). P. mirabilis causes between 10-44\% of 
41 catheter-associated urinary tract infections (CAUTIs), which are among the world's most

42

43

44

45

46

47

48

49

50

51

52

53

54

55

56

57

58

59

60

61

62

63

64

65

66

67

68

69

70

71

72

73

74

75

76

77

78

79

abundant nosocomial infections. CAUTIs typically occur in elderly patients who undergo longterm catheterization (Schaffer \& Pearson, 2015; Milo et al., 2017). Additionally, high-mortality (up to $50 \%$ in elderly patients) bacteremia and sepsis cases associated with P. mirabilis most frequently occur following UTIs and CAUTIs. Increasing rates of antimicrobial resistance in clinical $P$. mirabilis strains is a grave concern for nosocomial $P$. mirabilis infection severity (Luzzaro et al., 2001; Wang et al., 2014; Girlich et al., 2020). Alternative treatment avenues for Proteus-based infections are urgently needed (Milo et al., 2017; Alves et al., 2019).

P. mirabilis phages have been investigated as a treatment method for Proteus-based CAUTIs and associated catheter-blockages, for which established control strategies are lacking (Milo et al., 2017; Maszewska et al., 2018; Ujmajuridze et al., 2018; Gomaa et al., 2019). Byproducts of $P$. mirabilis biofilms in CAUTI cases lead to the production of crystalline aggregates which, in combination with biofilm growth, can dangerously obstruct the flow of a catheterized individual's urine (Schaffer \& Pearson, 2015; Milo et al., 2017). Multiple studies and patient trials have demonstrated the capacity for phages to inhibit the formation of $P$. mirabilis biofilms on catheter surfaces, which merits the further investigation and classification of P. mirabilis phages (Milo et al., 2017; Maszewska et al., 2018; Ujmajuridze et al., 2018; Gomaa et al., 2019). As of writing (Aug. 2020), fewer than 30 Proteus phage genome sequences are deposited in the public NCBI Genbank database (Sayers et al., 2020). The few characterized Proteus-specific phages are widely variable in morphology, genome sequence length, host range, and gene content (Prozesky, Klerk \& Coetzee, 1965; Alves et al., 2019).

In this study, classic growth assays and particle characterization demonstrate Privateer is a highly prolate (or elongated) podophage belonging to the rare C3 morphotype (Ackermann \& Eisenstark, 1974; Ackermann, 2001), and genomics suggest it is most closely related to the Kuraviruses.

\section{Materials \& Methods}

Phage isolation. Bacteriophage Privateer was isolated from filtered $(0.2 \mu \mathrm{m}$ pore size $)$ activated sludge sourced from a wastewater treatment facility in Navasota, TX. The phage was propagated on P. mirabilis strain ATCC 35659 aerobically at $30^{\circ} \mathrm{C}$ in Brain Heart Infusion (BHI, BD) media using the previously described soft-agar overlay method (Adams, 1956). Individual plaques that developed overnight on host lawns were picked into media and sterilized with $\mathrm{CHCl}_{3}$. The plaque purification was repeated three times prior to additional experiments.

To prepare high-titer lysates, a culture of ATCC 35659 was grown at $30^{\circ} \mathrm{C}$ with $180 \mathrm{rpm}$ shaking in BHI broth to $\mathrm{OD}_{550}$ of $0.2\left(\sim 5 \times 10^{7} \mathrm{cfu} / \mathrm{mL}\right)$. Phage were then adsorbed to the cells at $\mathrm{MOI}=0.1$. The cell + phage mixture was incubated for two hours $\left(30^{\circ} \mathrm{C}\right.$ with aeration at $\left.180 \mathrm{rpm}\right)$ to achieve culture lysis. The phage lysate was sterilized with $\mathrm{CHCl}_{3}$. Privateer was stored at $4^{\circ} \mathrm{C}$.

Peer) reviewing PDF | (2020:10:53564:1:0:NEW 25 Nov 2020) 
80

81

82

83

84

85

86

87

88

89

90

91

92

93

94

95

96

97

98

99

100

101

102

103

104

105

106

107

108

109

110

111

112

113

114

115

116

117

118

Phage purification. Privateer stocks were further concentrated and purified as previously described (Zeng et al., 2010). First, $500 \mathrm{~mL}$ of phage lysate was treated with $1 \mu \mathrm{g} / \mathrm{mL}$ of DNase/RNase (VWR), followed by precipitation with 10\% wt/vol PEG-8000 and $1 \mathrm{M} \mathrm{NaCl}$. The particles were resuspended in $\mathrm{SM}$ buffer $\left(100 \mathrm{mM} \mathrm{NaCl}, 1 \mathrm{M} \mathrm{MgSO}_{4}, 1 \mathrm{M}\right.$ Tris-HCl pH 7.5). Next, $\mathrm{CHCl}_{3}$ was added 1:1 to the suspension to separate the PEG-8000 from the phages. This concentrated phage lysate was ultracentrifuged using a $\mathrm{CsCl}$ step gradient $(1.3 \mathrm{~g} / \mathrm{mL}, 1.5 \mathrm{~g} / \mathrm{mL}$, and $1.7 \mathrm{~g} / \mathrm{mL} \mathrm{CsCl}$ ), extracted, and subjected to $\mathrm{CsCl}$ equilibrium centrifugation. The band corresponding to phage Privateer was extracted (to obtain a volume of $\sim 400-\mu \mathrm{L}$ ) and subsequently dialyzed three times against $600 \mathrm{~mL}$ of SM buffer.

Phage morphology determination. CsCl-purified Privateer particles were negatively stained with $2 \%$ uranyl acetate via the Valentine method and viewed by transmission electron microscopy at the Texas A\&M Microscopy and Imaging Center (Valentine, Shapire \& Stadtman, 1968).

Adsorption assay. BHI was inoculated 1:200 with an overnight culture of $P$. mirabilis ATCC 35659, then incubated shaking at $30^{\circ} \mathrm{C}$ until reaching exponential phase at $\mathrm{OD}_{550} 0.2$. After chilling on ice for 10 minutes, the cells were pelleted $\left(10,000 \mathrm{x} \mathrm{g}, 10\right.$ minutes, $\left.4^{\circ} \mathrm{C}\right)$, then resuspended in cold BHI. Phage were added at an MOI $=0.01$ and incubated on ice. At each time point, a $200 \mu \mathrm{L}$ aliquot was taken from the cell+phage mixture and centrifuged $(17,000 \mathrm{x} \mathrm{g}, 2$ minutes, $4^{\circ} \mathrm{C}$ ). The residual phage particles in the aliquot supernatants were immediately quantified by soft-agar overlay plaque assay. The fraction of adsorbed phages at each time point was calculated as the titer of the supernatant divided by the titer at the initial time point (Hernandez-Morales et al., 2018).

One-step growth curve. The latent period and burst size of Privateer were assayed via a one-step growth curve experiment performed in triplicate as in Hernandez-Morales et al. 2018 (Hernandez-Morales et al., 2018). P. mirabilis ATCC 35659 was grown to exponential phase and Privateer phage was adsorbed at $\mathrm{MOI}=0.01$ as described above. After a 20 minute cold incubation, cells were pelleted $\left(10,000 \mathrm{x} \mathrm{g}, 5\right.$ minutes, $\left.4^{\circ} \mathrm{C}\right)$ to remove non-adsorbed phages and resuspended in fresh, cold BHI. The cells + phage mixture was then diluted into 1:2000 into prewarmed $\mathrm{BHI}$ and incubated at $30^{\circ} \mathrm{C}$ with $225 \mathrm{rpm}$ shaking. At each time point, a sample was plated in Nutrient Broth (BD Difco) 0.75\% top agar with P. mirabilis ATCC 35659 on Nutrient Broth $1.5 \%$ agar plates. The zero time point was also treated with chloroform prior to plating to allow measurement of infective centers. Burst size in pfu per infected cell was calculated as the ratio of ending phage titer to the number of infective centers (starting titer minus free phage titer as measured with chloroform treatment). Average and standard deviation were calculated from three replicates. 
119

120

121

122

123

124

125

126

127

128

129

130

131

132

133

134

135

136

137

138

139

140

141

142

143

144

145

146

147

148

149

150

151

152

153

154

155

156

157

158

Lysis assays. $P$. mirabilis ATCC 35659 was grown and infected with Privateer at MOI = 10 as described above. $\mathrm{OD}_{550}$ measurements of the culture were taken over time.

From MOI = 3 infections, $1.5 \mathrm{ul}$ samples were observed between 60-80 minutes postinfection on a glass slide with a coverslip at $100 \mathrm{X}$ magnification under oil immersion on a Zeiss Axio Observer 7 inverted microscope through lysis of single cells. Time series images were processed using the Zeiss Zen 2.3 software.

Host range. The host range of Privateer was analyzed by pipetting $10 \mu \mathrm{L}$ quantities of serial dilutions of a high titer lysate $\left(\sim 10^{10} \mathrm{pfu} / \mathrm{mL}\right)$ on lawns of selected Proteus mirabilis strains. All strains, except B446 which was acquired from GangaGen Biotechnologies Private Limited (India), were from ATCC (Table 1). Expanded host range Gammaproteobacteria strains were Escherichia coli MG1655 (lab stocks), Klebsiella pneumoniae 1776c, a pKpQIL plasmidcured derivative of K. pneumoniae strain 1776c (Satlin et al., 2017), and Serratia marcescens D1 (no. 8887172; Ward's Science). Bacteria were considered sensitive to Privateer if single plaques were observed at phage concentrations above the detection limit established with the isolation host $\left(\geq 10^{2} \mathrm{pfu} / \mathrm{mL}\right)$ after incubation at $30^{\circ} \mathrm{C}$. Similar results were observed in three replicates.

gDNA preparation, sequencing, and assembly. Genomic DNA was purified from the phage as previously described with the Promega Wizard DNA clean-up system (Summer, 2009) after PEG precipitation, prepared as Illumina TruSeq Nano low-throughput libraries with 550-bp inserts using a Nextera DNA Flex Library Prep kit, and sequenced in paired-end 250-bp reads via Illumina MiSeq v2 300-cycle chemistry. The 396,576 sequence reads from the index containing the phage genome were quality controlled with FastQC

(http://www.bioinformatics.babraham.ac.uk/projects/fastqc/). The phage genome was assembled into a single raw contig via SPAdes v.3.5.0 with 636.7-fold coverage after trimming with the FASTX-Toolkit 0.0.14 (http://hannonlab.cshl.edu/fastx_toolkit/) (Bankevich et al., 2012). PCR amplification across the raw contig ends (forward primer 5'-ctcgttaccagcgcagaaa-3' and reverse primer 5'-caggtgctaaccaaggtttagg-3') accompanied by Sanger sequencing of the DNA product verified that the contig sequence was complete. Analyses with PhageTerm indicate a novel ends type (Garneau et al., 2017).

Genome annotation. The Privateer complete contig was assembled, analyzed, and annotated in the Center for Phage Technology Galaxy and Web Apollo interfaces (https://cpt.tamu.edu/galaxy-pub), as described by Ramsey and Rasche et al. (Ramsey et al., 2020). Briefly, protein-coding gene predictions relied on Glimmer v3.0 and MetaGeneAnnotator v1.0 (Delcher et al., 2007; Noguchi, Taniguchi \& Itoh, 2008). ARAGORN v2.36 was run to detect tRNA coding sequences (Laslett \& Canback, 2004). Seven rho-independent termination sites were annotated using TransTermHP v2.09 when scores were $>90$, the stem was at least $5 \mathrm{bp}$ in length, and at least four T's were downstream (Kingsford, Ayanbule \& Salzberg, 2007). For functional assignments, predicted gene functions were assigned using InterProScan v5.33-72, , 
159 BLAST v2.2.31 with a 0.001 maximum expectation value, and TMHMM v2.0 at the default 160 settings (Krogh et al., 2001; Camacho et al., 2009; Jones et al., 2014). All BLAST queries were 161 run against the NCBI nonredundant and UniProtKB Swiss-Prot and TrEMBL databases

162 (Coordinators et al., 2017; Consortium, 2019).

163 Supporting analysis was performed using the HHSuite v3.0 HHpred tool (multiple 164 sequence alignment generation with the HHblits ummiclus30_2018_08 database and modeling 165 with PDB_mmCIF70) (Zimmermann et al., 2018).

166 The genome sequence and associated data for phage Privateer were deposited under 167 GenBank accession no. MT028297, BioProject accession no. PRJNA222858, Sequence Read

168 Archive accession no. SRR11024936, and BioSample accession no. SAMN14002513. Proteus 169 phage Privateer is the proposed species submitted to the International Committtee on Taxonomy 170 of Viruses (ICTV) for consideration. The genome map was prepared using the Genome Linear 171 Plot tool in CPT Galaxy, modified from DNA features viewer (Zulkower \& Rosser, 2020;

172 Ramsey et al., 2020).

173

Comparative genomics. Initial Privateer DNA sequence similarity to other phage genomes was determined using the progressiveMauve v2.4.0 alignment algorithm coupled with MIST (Darling, Mau \& Perna, 2010; Ramsey et al., 2020). Protein similarity with other phages was calculated with BLAST v2.2.31 using a 0.001 maximum expectation value and the relatedness tools in CPT Galaxy.

Records for the top related phage classifications, including many unclassified podoviruses and several in the genus Kuravirus as presented in the NCBI Taxonomy and the International Committee on Viral Taxonomy (Lefkowitz et al., 2017; Schoch et al., 2020), were retrieved for comparison (Table 2). C3 podophage proteins were used to generate a BLAST database and each protein was queried against this database via BLASTp (expectation value cutoff $=10^{-20}$ ). A greedy algorithm grouped the coding sequences into clusters, which were aligned with ClustalW and presented as locally colinear blocks (LCBs) in an XMFA file (Larkin et al., 2007). Adjacent LCBs below the threshold distance of 50 nucleotides were consolidated. $\mathrm{X}$-Vis, a custom XMFA visualization tool created in JavaScript, rendered the genomes and their LCB alignments (Ramsey et al., 2020). Figures were sized and labelled in Inkscape (Project, n.d.).

190

Analysis of phage structural proteins by mass spectrometry. All phage protein analyses were performed using samples from the $\mathrm{CsCl}$-purified Privateer stock. The total protein mass in the CsCl-purified stock was determined via Bradford assay according to manufacturer recommendations (Bio-Rad). To get a view of structural protein complexity prior to mass spectrometry, CsCl-purified Privateer particles were separated by SDS-PAGE on a Bio-Rad 4$20 \%$ Tris-glycine gel with $\sim 10^{11} \mathrm{pfu} / \mathrm{mL}$ per lane. The gel was stained with Coomassie blue

197 (0.1\% Coomassie R-250, 10\% acetic acid, 40\% methanol). Prestained SeeBlue-Plus2

198 (Invitrogen) was used as a molecular weight marker. This was for visual inspection only, as 
199

200

201

202

203

204

205

206

207

208

209

210

211

212

213

214

215

216

217

218

219

220

221

222

223

224

225

226

227

228

229

230

231

232

233

234

235

236

237

238

whole phage particles, rather than individual bands, were the starting sample for mass spectrometry.

A sample of whole Privateer particles from CsCl-purified stock was prepared for mass spectrometry analysis by methanol-chloroform precipitation with a 6:1.5:2 methanol:chloroform:water ratio. Approximately $50 \mu \mathrm{g}$ of extracted phage particles were treated with $5 \%$ SDS, then a nuclease cocktail that contained DNase at $10 \mu \mathrm{g} / \mathrm{mL}$ (Type II, Sigma) and RNase at $50 \mu \mathrm{g} / \mathrm{mL}$ (Type IIIa, Sigma) in $10 \mathrm{mM}$ Tris at pH 7.0, for 15 minutes on ice. The treated sample was then applied to an S-Trap column (Protifi) and processed according to the manufacturer protocol. All proteins were reduced on-column with DTT and alkylated with iodoacetamide prior to digestion with modified porcine trypsin (Promega). Resulting peptides were collected and dried prior to LC-MS/MS analysis.

After shipment, the sample was resuspended in $0.5 \%$ acetic acid $/ 0.005 \%$ trifluoroacetic acid for HPLC-electrospray ionization-tandem mass spectrometry (HPLC-ESI-MS/MS) accomplished on a Thermo Fisher LTQ Orbitrap Velos Pro mass spectrometer (Thomas et al., 2010; Weintraub et al. 2018). Mascot (Matrix Science; London, UK) was used to search the MS files against a database of sequences for predicted proteins for phage Privateer (146 sequences; 28,814 residues) and the SwissProt database [SwissProt 2019_10 (561,356 sequences; $201,858,328$ residues)] similar to previously described studies of other phage proteins (Thomas et al., 2010; Weintraub et al. 2018). Subset searching of the Mascot output by X! Tandem, determination of probabilities of peptide assignments and protein identifications, and cross correlation of the Mascot and X! Tandem identifications were accomplished by Scaffold 4 (Proteome Software).

Phylogenetic analysis. Homologous structural proteins for Privateer portal protein (NCBI accession QIN94795.1), scaffolding protein (QIN94797.1), major capsid protein (QIN94798.1), and tail tubular protein (QIN94802.1) were identified via CoreGenes3.5 (Turner et al., 2013). Alignments were generated with MUSCLE (Edgar, 2004). Maximum likelihood analysis was run with a bootstrap value of 100 via Phylogeny.fr, and the tree was constructed using TreeDyn (Castresana, 2000; Guindon \& Gascuel, 2003; Anisimova \& Gascuel, 2006; Chevenet et al., 2006; Dereeper et al., 2008, 2010).

\section{Results}

\section{Privateer Isolation and Characterization}

Bacteriophage Privateer was isolated in 2019 from activated sludge obtained at a wastewater treatment facility in Navasota, Texas. Plaques produced by Privateer when plated on P. mirabilis strain ATCC 35659 are clear and approximately $0.15-\mathrm{mm}$ in diameter (Fig. 1A). The phage was purified via ultracentrifugation on a cesium gradient for use in further proteomic and infection cycle characterization (Fig. 1B). Transmission electron microscopy (TEM) imaging of the negatively-stained purified phage particles demonstrated that Privateer is a podophage with 
239 C3 morphology, typified by the elongated capsid (Fig. 1C) (Ackermann, 2001). The virion head

240 is $\sim 140$-nm in length and $\sim 35-\mathrm{nm}$ in diameter, with a short $\sim 10-\mathrm{nm}$ tail.

241

242

\section{Privateer Infection Kinetics and Lysis}

243

244

To assay Privateer growth, we determined that nearly $80 \%$ of the phages were adsorbed

245 to host cells within eight minutes post-phage addition (Fig. 2A). From a one-step growth curve, an average $138 \pm 56$ burst size was calculated (Fig. 2B). At higher multiplicity of infection (MOI), Privateer induces host growth cessation within 40 minutes, but overt lysis does not begin until 100 minutes and lasts $\sim 40$ minutes in bulk culture (Fig. 2C). Individual infected host cells were observed by oil immersion to reveal an abrupt and destructive explosion associated with cell lysis after comparatively little change to the cell appearance through that point (see Supp.

250 Movies).

251

252

\section{Phage Host Range}

253

The host range for phage Privateer was assayed via spot-dilution against a bacterial panel including six $P$. mirabilis strains, mainly uncharacterized clinical isolates (Table 1). Privateer produced smaller plaques on four $P$. mirabilis strains at a significantly reduced efficiency of plating (EOP $<10^{-3}$ ). Additionally, the phage produced faint clearing, distinctive of killing from

257 without, on $P$. mirabilis ATCC 43071 in high titer spots $\left(>10^{9} \mathrm{pfu} / \mathrm{mL}\right)$. Privateer did not plaque on strain B446 or any other tested Gammaproteobacteria: Escherichia coli MG1655, Klebsiella

259 pneumoniae 1776c, and Serratia marcescens D1.

260

261

\section{Privateer Genome Annotation}

262

263

The 90.71-kb Privateer genome was assembled into a single contig with $636.7 x$ coverage.

264 The Privateer genome encodes 144 proteins, at an 88.3\%, coding density, of which 43 were assigned predicted functions (Fig. 3). A $34.52 \% \mathrm{G}+\mathrm{C}$ content for the Privateer genome stands in contrast to the consistent $39 \% \mathrm{G}+\mathrm{C}$ content of Proteus genomes (Falkow, Ryman \& Washington, 1962; Pearson et al., 2008; Sullivan et al., 2013).

267

268

269

\section{Comparative Genomics}

270

Phage Privateer shares $83.1 \%$ nucleotide sequence identity with Cronobacter phage

271

vB_CsaP_009. Privateer and vB_CsaP_009 both share low nucleotide sequence identity $(<10 \%)$

272 with all other known phages. Despite low nucleotide similarity, BLASTp results demonstrated

273 that in addition to 128 similar proteins between Privateer and vB_CsaP_009, several other phages also encode numerous similar proteins. These include Cronobacter phage vB_CsaP_GAP52 (71 proteins), Salmonella phage 7-11 (65 proteins) (Kropinski, Lingohr \& Ackermann, 2011), Aeromonas phage Lah_6 (45 proteins) (Kabwe et al., 2020), and Vibrio phage Vp_R1 (34 proteins) (Ren et al., 2019). TEM imaging demonstrated that phages 7-11, Lah_6, and Vp_R1 each belong to the C3 podophage morphotype. Privateer also shares similar proteins with phages in the Kuravirus genus, including Escherichia phages phiEco32 (33 similar 
279 proteins) (Savalia et al., 2008), Paul (33 proteins) (Holt et al., 2019), and vB_EcoP_SU10 (32

280 similar proteins) (Mirzaei et al., 2014). The Kuravirus genus is within the Podoviridae family

281 and consists of C3 morphotype (prolate) phages, with phiEco32 as the exemplar. We conclude

282 that Privateer is phiEco32-like, and below compare and contrast with a select group of C3

283 morphotype phages (Table 2 and Fig. 4).

284

285

286

287

Virion Protein Analysis

SDS-PAGE and mass spectrometry analyses of Privateer particles verified the presence of ten predicted virion-associated proteins, including the portal protein (QIN94795), minor

288 (QIN94799) and major (QIN94798) capsid proteins, and tail tubular protein (QIN94802) (Fig.

289 5). The major capsid gene contains a programmed ribosomal frameshift signal (GGGAAAG)

290

291

292 predicted to result in a second, larger, minor capsid protein, as demonstrated for phage T7 proteins 10A and 10B, among others (Sipley et al., 1991). The two bands for capsid protein products expected from a translational frameshift were observed by SDS-PAGE (Fig. 5A). Both

293 suspected capsid protein bands are migrating at an apparent molecular mass higher than the calculated molecular weight. While this could be an artifact of comparison to a stained protein

295 ladded, further characterization is required to verify the state of the capsid protein. The minor

296

297 capsid protein was detected in virions via mass spectrometry (Fig. 5B). Although, the use of whole virions containing a mixture of all structural proteins precludes a definitive identification of the major capsid protein, the capsid and its frameshifted product were observed in both phiEco32 and vB_EcoP_SU10 (Savalia et al., 2008; Mirzaei et al., 2014), indicating its conservation among phiEco32-like phages.

301

302

303

304

305

306

307

\section{Structural Region Phylogenetic Comparison}

A phylogenetic tree depicting the evolutionary relatedness of Privateer and selected C3 podophages on the basis of the presence of major capsid and three other conserved structural proteins suggests that the $\mathrm{C} 3$ phages descend from a common ancestor and diverge into two distinct clades: the Kuravirus and non-Kuravirus phages (Fig. 6). The distances between the nonKuravirus phages are larger than those between the tightly grouped (e.g. more closely related)

309 Kuravirus phages.

\section{Discussion}

312

Though $P$. mirabilis is a significant human pathogen resulting in UTIs and CAUTIs, Privateer is among a small number of characterized virulent phages for this host. The prolate morphology observed in Privateer virions classifies it among C3 morphotype phages, with its closest related phages in the sequence database also primarily infecting Proteobacteria hosts. The limited host range data presented here should be further investigated in comparison to other

316 P. mirabilis phages, and likely in close conjunction with related phages of other

317 Enterobacterales. Genome inspection, and comparison with other phages, reveal that the

318 packaging and structural genes are organized in a modular fashion, however, the remainder of 
319 the Privateer genome is less distinctly grouped by gene function. Below, we discuss the genetic

320

321

322

323

324

325

326

327

328

329

330

331

332

333

334

335

336

337

338

339

340

341

342

343

344

345

346

347

348

349

350

351

352

353

354

355

356

357

358 repertoire for both expected functional predictions and several features unusual to phage genomes.

DNA packaging. The DNA packaging protein terminase (NCBI accession QIN94794), is highly conserved across $\mathrm{C} 3$ morphotype phages examined in this report. The terminase shares $\sim 60 \%$ amino acid sequence identity with Kuravirus phages and $\geq 70 \%$ identity with the nonKuravirus phage terminases. The packaging strategy for the Kuravirus phages phiEco32, Paul, and vB_EcoP_SU10 was predicted to involve direct terminal repeats $(<200-b p)$ similar to the packaging approach of Escherichia phage T7 (Chung \& Hinkle, 1990). Using the PhageTerm algorithm, Privateer is predicted to have novel end types, and the non-Kuravirus phages discussed here have not been investigated in this way.

Lysis. Three lysis proteins were identified: an inner- and outer-spanin (QIN94818, QIN94817) and an endolysin endopeptidase (QIN94840). The two spanin proteins are located immediately following the last structural protein (QIN94816), while the endolysin is situated $\sim 12-\mathrm{kb}$ downstream (Fig. 3). The endolysin protein has $96 \%$ amino acid identity to its homolog in vB_CsaP_009, and 52\% similarity to vB_CsaP_GAP52 endolysin. The shared conserved domains with high amino acid identity suggest that these endolysin proteins might be active against the peptidoglycan of both bacterial cells. A holin gene could not be reliably identified in the Privateer genome. Ten proteins with unknown functions contain at least one transmembrane domain, and are therefore potential holin candidates (Young, 2002). Unlike Privateer, the Kuravirus phages each encode a putative holin and endolysin among the morphogenesis genes, possibly a grouping of late genes (Fig. 4).

Biosynthesis. Privateer encodes several biosynthesis proteins, including four ribonucleotide reductases (QIN94826, QIN94860, QIN94873, QIN94874), two nicotinate ribosyltransferases (QIN94828, QIN94907), a deoxycytidylate deaminase (QIN94864), a deoxyribosyltransferase superfamily protein (QIN94829), and a polynucleotide kinase (QIN94912). The only two Privateer biosynthesis proteins with homologs in Kuravirus phages are the deoxycytidylate deaminase and a glutamine amidotransferase domain-containing protein. Given the several nucleotide metabolism proteins present in Privateer, but not in Kuravirus genomes, efficient replication of Privateer DNA may require additional machinery.

Stress response and regulation. The genome additionally encodes four proteins associated with responses to chemical stress: a thioredoxin (QIN94863) and three tellurium resistance, or ter, proteins (QIN94906, QIN94916, QIN94918). When expressed as elements of bacterial genomes, ter proteins are involved in cellular processes such as the regulation of chemical stress responses and phage resistance (Whelan, Colleran \& Taylor, 1995; Anantharaman, Iyer \& Aravind, 2012). Tellurite resistance has also been positively correlated with phage resistance (Tomás et al., 1984). The specific role of ter proteins expressed by phage genomes has not yet been established experimentally. Although the three ter stress response proteins are absent in the Kuravirus-like phages, the thioredoxin is conserved across each $\mathrm{C} 3$ morphotype phage examined in this report. Thioredoxins facilitate a wide range of functions in

Peer) reviewing PDF | (2020:10:53564:1:0:NEW 25 Nov 2020) 
359

360

361

362

363

364

365

366

367

368

369

370

371

372

373

374

375

376

377

378

379

380

381

382

383

384

385

386

387

388

389

390

391

392

393

394

395

396

397

398

different organisms, including the reduction of potentially harmful reactive oxygen species and controlling the structure or catalytic activity of proteins via manipulation of thiol-group redox states (Arnér \& Holmgren, 2000). Additionally, thioredoxins play critical roles in nucleotide metabolism as electron donors for ribonucleotide reductases and other biosynthesis proteins. Past structural and enzymatic assays demonstrated that Escherichia phage T7 DNA polymerase binding affinity for primer sequences is improved $\sim 80$-fold by coupling with host thioredoxin (Huber, Tabor \& Richardson, 1987; Bedford, Tabor \& Richardson, 1997). HHpred analysis predicted significant structural similarity between Privateer DNA polymerase (QIN94848) and T7 DNA polymerase (NP_041960). Privateer thioredoxin (QIN94863) is also predicted to have significant structural similarity at $>99 \%$ probability across $>75 \%$ of the protein to thioredoxins of various organisms by HHPred. We hypothesize that the Privateer thioredoxin may similarly couple with its DNA polymerase to improve processivity, thus enhancing the rate of phage DNA replication, and explaining the presence of homologs for both proteins in each $\mathrm{C} 3$ phage examined in this study.

DNA replication and recombination. Privateer encodes proteins involved in DNA replication and recombination including a DNA adenine methylase (QIN94821), DNA polymerase (QIN94848), DNA primase/helicase (QIN94866), DNA ligase (QIN94832), and two exonucleases (QIN94834, QIN94865). The Kuravirus genomes encode homologs for the DNA polymerase, DNA primase/helicase, and both exonucleases. A vB_CsaP_009 protein (BBU72708) shares $92.82 \%$ amino acid sequence identity with the DNA adenine methylase, yet no homologs nor additional DNA methylases were found within the other $\mathrm{C} 3$ phages (including Cronobacter phage vB_CsaP_GAP52). This could indicate that Privateer DNA within $P$. mirabilis requires methylation for either increased transcription efficiency or to defend against a host anti-phage response not active in another host species (Murphy et al., 2013).

Privateer additionally encodes an RtcB-like RNA ligase (QIN94896), which has a homolog in vB_CsaP_009 and vB_CsaP_GAP52. Studies have shown RtcB RNA ligase involvement in ribosome homeostasis and RNA repair in bacteria and certain eukaryotes (Tanaka, Meineke \& Shuman, 2011; Chakravarty et al., 2012; Engl et al., 2016). The Privateer RtcB-like RNA ligase is located $\sim 1-\mathrm{kb}$ downstream from a cluster of three tRNA genes (Arg anticodons TCT and CCT, Met/Ile2 anticodon CAT) (Chan \& Lowe, 2019), and the genome also encodes a fourth tRNA gene (Trp anticodon CCA) $\sim 15 \mathrm{~kb}$ further downstream (Fig. 4). The Kuravirus phages code for one tRNA gene at most, though not the same tRNA. Privateer's RtcBlike RNA ligase may ensure tRNAs remain stable and in sufficient quantity within the host to facilitate the rapid production of phage proteins, as suggested for certain mycophages encoding $>20$ tRNAs (Pope et al., 2014). Phages often encode transfer RNA genes if their specific host does not provide adequate tRNAs for efficient phage protein synthesis, or as a strategy to allow host switching (Bailly-Bechet, Vergassola \& Rocha, 2007; Delesalle et al., 2016). There is not a strong correlation between codon usage in the host and Privateer (data not shown). Therefore, the lack of tRNA conservation within Proteus phages does not shed light on a specific host deficiency. 
Additional genome features. The only Privateer protein with an explicit role in transcriptional regulation was an alternative RNA polymerase extracytoplasmic function (ECF) sigma factor (QIN94836). Homologs for the ECF sigma factor are present in the Kuravirus phages and the phiEco32 RNA polymerase sigma factor was experimentally shown to bind to $E$. coli RNA polymerase (Savalia et al., 2008). An autoregulation sequence within the deduced promoter binding region near the -35 sequence has weak conservation of an expected homopolymeric T-tract, but other elements vary (Mascher, 2013; Guzina \& Djordjevic, 2017). The phage ECF sigma factor subgroup is considered an outlier compared to canonical families, and may employ flexible binding strategies that allow promoter recognition (Guzina \& Djordjevic, 2016). Additionally, no clear candidates for a soluble or membrane-bound anti-sigma factor were annotated in the Privateer genome.

The predicted DNA-binding Dps family protein (QIN94861) was detected by mass spectrometry with purified virions (Fig. 5). While its function in Privateer infection has not been verified, Dps family homologs are also present in the Kuravirus phages.

\section{Conclusions}

Privateer is the first prolate podophage reported to infect Proteus hosts, and exhibits typical characteristics for Caudovirales infection, including explosive lysis behavior. The host range here assayed for Privateer is relatively narrow, and its closest known genetic relative infects Cronobacter, another Proteobacteria. In the Privateer genome we predicted protein functions for morphogenesis, lysis, DNA replication and recombination, and biosynthesis among others, though these displayed limited modular organization. Proteomic analysis on whole phage particles verified the presence of predicted structural proteins, including a longer capsid protein hypothesized to arise by a translational frameshift mechanism. Phylogenetic analysis performed using the amino acid sequences of four conserved structural proteins (including the major capsid protein) illustrated Privateer relatedness to other C3 morphotype bacteriophages. Some Privateer proteins share amino acid identity with proteins found in other $\mathrm{C} 3$ phages, including the phages classified in the Kuravirus genus. Several additional interesting genome features were noted, including the presence of an RtcB-like RNA ligase, an ECF RNA polymerase sigma factor, and three ter stress response proteins. Individual phage characterizations such as the one presented here are an essential beginning step for building a larger panel of diverse Proteus phages to investigate within infection models in combination. As less than 30 Proteus phage genomes have thus far been sequenced, a broader collection of Proteus phages should be sequenced and studied at the bench if phages like Privateer are to be used as alternative treatments of CAUTIs in the future. Current comparisons to related phages isolated on other bacterial hosts can promote such studies in both therapeutic and basic phage research contexts.

\section{Acknowledgments}


439

440

441

442

443

444

445

446

447

448

449

450

451

452

453

454

455

456

457

458

459

460

461

462

463

464

465

466

467

468

469

470

471

472

473

474

475

476

477

The initial stages of this project were completed in partial fulfillment of BICH464 Bacteriophage Genomics requirements, an undergraduate course at Texas A\&M University in the Department of Biochemistry \& Biophysics. We are grateful for the advice and assistance from the Center for Phage Technology staff, in particular Mei Liu, James Clark, and Isla Hernandez.

We acknowledge and thank the Protein Chemistry Laboratory at Texas A\&M University for their guidance and assistance in preparing sample for the mass spectrometry analysis. Mass spectrometry analyses were conducted in the Institutional Mass Spectrometry Laboratory of the University of Texas Health Science Center at San Antonio. The expert technical assistance of Sammy Pardo, Dana Molleur, and Susan T. Weintraub is greatly appreciated.

\section{References}

Ackermann H-W. 2001. Frequency of morphological phage descriptions in the year 2000 . Archives of Virology 146:843-857. DOI: 10.1007/s007050170120.

Ackermann H-W, Eisenstark A. 1974. The Present State of Phage Taxonomy. Intervirology 3:201-219. DOI: 10.1159/000149758.

Adams MH. 1956. Bacteriophages. Interscience Publishers, Inc. New York.

Alves DR, Nzakizwanayo J, Dedi C, Olympiou C, Hanin A, Kot W, Hansen L, Lametsch R, Gahan CGM, Schellenberger P, Ogilvie LA, Jones BV. 2019. Genomic and Ecogenomic Characterization of Proteus mirabilis Bacteriophages. Frontiers in microbiology 10:1783. DOI: 10.3389/fmicb.2019.01783.

Anantharaman V, Iyer LM, Aravind L. 2012. Ter-dependent stress response systems: novel pathways related to metal sensing, production of a nucleoside-like metabolite, and DNAprocessing. Molecular BioSystems 8:3142-3165. DOI: 10.1039/c2mb25239b.

Anisimova M, Gascuel O. 2006. Approximate Likelihood-Ratio Test for Branches: A Fast, Accurate, and Powerful Alternative. Systematic Biology 55:539-552. DOI: 10.1080/10635150600755453.

Armbruster CE, Mobley HLT, Pearson MM. 2018. Pathogenesis of Proteus mirabilis Infection. EcoSal Plus 8. DOI: 10.1128/ecosalplus.esp-0009-2017.

Arnér ESJ, Holmgren A. 2000. Physiological functions of thioredoxin and thioredoxin reductase. European Journal of Biochemistry 267:6102-6109. DOI: 10.1046/j.14321327.2000.01701.x.

Bailly-Bechet M, Vergassola M, Rocha E. 2007. Causes for the intriguing presence of tRNAs in phages. Genome Research 17:1486-1495. DOI: 10.1101/gr.6649807.

Bankevich A, Nurk S, Antipov D, Gurevich AA, Dvorkin M, Kulikov AS, Lesin VM, Nikolenko SI, Pham S, Prjibelski AD, Pyshkin AV, Sirotkin AV, Vyahhi N, Tesler G, Alekseyev MA, Pevzner PA. 2012. SPAdes: a new genome assembly algorithm and its applications to single- 
478

479

480

481

482

483

484

485

486

487

488

489

490

491

492

493

494

495

496

497

498

499

500

501

502

503

504

505

506

507

508

509

510

511

512

513

514

515

516

cell sequencing. Journal of computational biology : a journal of computational molecular cell biology 19:455-477. DOI: 10.1089/cmb.2012.0021.

Bedford E, Tabor S, Richardson CC. 1997. The thioredoxin binding domain of bacteriophage T7 DNA polymerase confers processivity on Escherichia coli DNA polymerase I. Proceedings of the National Academy of Sciences 94:479-484. DOI: 10.1073/pnas.94.2.479.

Camacho C, Coulouris G, Avagyan V, Ma N, Papadopoulos J, Bealer K, Madden TL. 2009. BLAST+: architecture and applications. BMC bioinformatics 10:421. DOI: 10.1186/14712105-10-421.

Castresana J. 2000. Selection of Conserved Blocks from Multiple Alignments for Their Use in Phylogenetic Analysis. Molecular Biology and Evolution 17:540-552. DOI: 10.1093/oxfordjournals.molbev.a026334.

Chakravarty AK, Subbotin R, Chait BT, Shuman S. 2012. RNA ligase RtcB splices 3'-phosphate and 5'-OH ends via covalent RtcB-(histidinyl)-GMP and polynucleotide-(3')pp(5')G intermediates. Proceedings of the National Academy of Sciences 109:6072-6077. DOI: 10.1073/pnas. 1201207109.

Chan PP, Lowe TM. 2019. Gene Prediction, Methods and Protocols. Methods in molecular biology (Clifton, N.J.) 1962:1-14. DOI: 10.1007/978-1-4939-9173-0_1.

Chevenet F, Brun C, Bañuls A-L, Jacq B, Christen R. 2006. TreeDyn: towards dynamic graphics and annotations for analyses of trees. BMC Bioinformatics 7:439. DOI: 10.1186/1471-21057-439.

Chung Y-B, Hinkle DC. 1990. Bacteriophage T7 DNA Packaging II. Analysis of the DNA sequences required for packaging using a plasmid transduction assay. Journal of Molecular Biology 216:927-938. DOI: 10.1016/s0022-2836(99)80011-4.

Consortium U. 2019. UniProt: a worldwide hub of protein knowledge. Nucleic acids research 47:D506-D515. DOI: 10.1093/nar/gky1049.

Coordinators NR, Agarwala R, Barrett T, Beck J, Benson DA, Bollin C, Bolton E, Bourexis D, Brister JR, Bryant SH, Canese K, Cavanaugh M, Charowhas C, Clark K, Dondoshansky I, Feolo M, Fitzpatrick L, Funk K, Geer LY, Gorelenkov V, Graeff A, Hlavina W, Holmes B, Johnson M, Kattman B, Khotomlianski V, Kimchi A, Kimelman M, Kimura M, Kitts P, Klimke W, Kotliarov A, Krasnov S, Kuznetsov A, Landrum MJ, Landsman D, Lathrop S, Lee JM, Leubsdorf C, Lu Z, Madden TL, Marchler-Bauer A, Malheiro A, Meric P, KarschMizrachi I, Mnev A, Murphy T, Orris R, Ostell J, O’Sullivan C, Palanigobu V, Panchenko AR, Phan L, Pierov B, Pruitt KD, Rodarmer K, Sayers EW, Schneider V, Schoch CL, Schuler GD, Sherry ST, Siyan K, Soboleva A, Soussov V, Starchenko G, Tatusova TA, Thibaud-Nissen F, Todorov K, Trawick BW, Vakatov D, Ward M, Yaschenko E, Zasypkin A, Zbicz K. 2017. Database resources of the National Center for Biotechnology Information. Nucleic acids research 46:D8-D13. DOI: 10.1093/nar/gkx1095.

Darling AE, Mau B, Perna NT. 2010. progressiveMauve: multiple genome alignment with gene gain, loss and rearrangement. PloS one 5:e11147. DOI: 10.1371/journal.pone.0011147. 
517 Delcher AL, Bratke KA, Powers EC, Salzberg SL. 2007. Identifying bacterial genes and 518 endosymbiont DNA with Glimmer. Bioinformatics 23:673-679. DOI:

519 10.1093/bioinformatics/btm009.

520

521

522

523

524

525

526

527

528

529

530

531

532

533

534

535

536

537

538

539

540

541

542

543

544

545

546

547

548

549

550

551

552

553

554

555

Delesalle VA, Tanke NT, Vill AC, Krukonis GP. 2016. Testing hypotheses for the presence of tRNA genes in mycobacteriophage genomes. Bacteriophage 6:e1219441. DOI: 10.1080/21597081.2016.1219441.

Dereeper A, Audic S, Claverie J-M, Blanc G. 2010. BLAST-EXPLORER helps you building datasets for phylogenetic analysis. BMC Evolutionary Biology 10:8. DOI: 10.1186/14712148-10-8.

Dereeper A, Guignon V, Blanc G, Audic S, Buffet S, Chevenet F, Dufayard J-F, Guindon S, Lefort V, Lescot M, Claverie J-M, Gascuel O. 2008. Phylogeny.fr: robust phylogenetic analysis for the non-specialist. Nucleic Acids Research 36:W465-W469. DOI: 10.1093/nar/gkn180.

Drzewiecka D. 2016. Significance and Roles of Proteus spp. Bacteria in Natural Environments. Microbial ecology 72:741-758. DOI: 10.1007/s00248-015-0720-6.

Edgar RC. 2004. MUSCLE: multiple sequence alignment with high accuracy and high throughput. Nucleic Acids Research 32:1792-1797. DOI: 10.1093/nar/gkh340.

Engl C, Schaefer J, Kotta-Loizou I, Buck M. 2016. Cellular and molecular phenotypes depending upon the RNA repair system RtcAB of Escherichia coli. Nucleic Acids Research 44:9933-9941. DOI: 10.1093/nar/gkw628.

Falkow S, Ryman IR, Washington O. 1962. Deoxyribonucleic Acid Base Composition of Proteus and Providence Organisms. Journal of Bacteriology 83:1318-1321. DOI: 10.1128/jb.83.6.1318-1321.1962.

Garneau JR, Depardieu F, Fortier L-C, Bikard D, Monot M. 2017. PhageTerm: a tool for fast and accurate determination of phage termini and packaging mechanism using next-generation sequencing data. Scientific reports 7:8292. DOI: 10.1038/s41598-017-07910-5.

Girlich D, Bonnin RA, Dortet L, Naas T. 2020. Genetics of Acquired Antibiotic Resistance Genes in Proteus spp. Frontiers in Microbiology 11:256. DOI: 10.3389/fmicb.2020.00256.

Gomaa S, Serry F, Abdellatif H, Abbas H. 2019. Elimination of multidrug-resistant Proteus mirabilis biofilms using bacteriophages. Archives of Virology 164:2265-2275. DOI: 10.1007/s00705-019-04305-x.

Guindon S, Gascuel O. 2003. A Simple, Fast, and Accurate Algorithm to Estimate Large Phylogenies by Maximum Likelihood. Systematic Biology 52:696-704. DOI: 10.1080/10635150390235520.

Guzina J, Djordjevic M. 2016. Promoter Recognition by Extracytoplasmic Function $\sigma$ Factors: Analyzing DNA and Protein Interaction Motifs. Journal of Bacteriology 198:1927-1938. DOI: $10.1128 / \mathrm{jb} .00244-16$.

Guzina J, Djordjevic M. 2017. Mix-and-matching as a promoter recognition mechanism by ECF $\sigma$ factors. BMC Evolutionary Biology 17:12. DOI: 10.1186/s12862-016-0865-z.

Peer) reviewing PDF | (2020:10:53564:1:0:NEW 25 Nov 2020) 
556 Hernandez-Morales AC, Lessor LL, Wood TL, Migl D, Mijalis EM, Russell WK, Young RF,

557

558

559

560

561

562

563

564

565

566

567

568

569

570

571

572

573

574

575

576

577

578

579

580

581

582

583

584

585

586

587

588

589

590

591

592

593

594

595

Gill JJ. 2018. Genomic and Biochemical Characterization of Acinetobacter Podophage Petty Reveals a Novel Lysis Mechanism and Tail-Associated Depolymerase Activity. Journal of Virology:JVI.01064-17. DOI: 10.1128/jvi.01064-17.

Holt A, Saldana R, Moreland R, Gill JJ, Liu M, Ramsey J. 2019. Complete Genome Sequence of Escherichia coli Phage Paul. Microbiology Resource Announcements 8. DOI: 10.1128/mra.01093-19.

Huber HE, Tabor S, Richardson CC. 1987. Escherichia coli thioredoxin stabilizes complexes of bacteriophage T7 DNA polymerase and primed templates. The Journal of biological chemistry 262:16224-32.

Jones P, Binns D, Chang H-Y, Fraser M, Li W, McAnulla C, McWilliam H, Maslen J, Mitchell A, Nuka G, Pesseat S, Quinn AF, Sangrador-Vegas A, Scheremetjew M, Yong S-Y, Lopez R, Hunter S. 2014. InterProScan 5: genome-scale protein function classification. Bioinformatics 30:1236-1240. DOI: 10.1093/bioinformatics/btu031.

Kabwe M, Brown T, Speirs L, Ku H, Leach M, Chan HT, Petrovski S, Lock P, Tucci J. 2020. Novel Bacteriophages Capable of Disrupting Biofilms From Clinical Strains of Aeromonas hydrophila. Frontiers in Microbiology 11:194. DOI: 10.3389/fmicb.2020.00194.

Kingsford CL, Ayanbule K, Salzberg SL. 2007. Rapid, accurate, computational discovery of Rho-independent transcription terminators illuminates their relationship to DNA uptake. Genome biology 8:R22. DOI: 10.1186/gb-2007-8-2-r22.

Krogh A, Larsson B, Heijne G von, Sonnhammer EL. 2001. Predicting transmembrane protein topology with a hidden Markov model: application to complete genomes. Journal of Molecular Biology 305:567-580. DOI: 10.1006/jmbi.2000.4315.

Kropinski AM, Lingohr EJ, Ackermann H-W. 2011. The genome sequence of enterobacterial phage 7-11, which possesses an unusually elongated head. Archives of virology 156:149151. DOI: 10.1007/s00705-010-0835-5.

Larkin MA, Blackshields G, Brown NP, Chenna R, McGettigan PA, McWilliam H, Valentin F, Wallace IM, Wilm A, Lopez R, Thompson JD, Gibson TJ, Higgins DG. 2007. Clustal W and Clustal X version 2.0. Bioinformatics 23:2947-2948. DOI: 10.1093/bioinformatics/btm404.

Laslett D, Canback B. 2004. ARAGORN, a program to detect tRNA genes and tmRNA genes in nucleotide sequences. Nucleic acids research 32:11-16. DOI: 10.1093/nar/gkh152.

Lefkowitz EJ, Dempsey DM, Hendrickson RC, Orton RJ, Siddell SG, Smith DB. 2017. Virus taxonomy: the database of the International Committee on Taxonomy of Viruses (ICTV). Nucleic Acids Research 46:gkx932-. DOI: 10.1093/nar/gkx932.

Luzzaro F, Perilli M, Amicosante G, Lombardi G, Belloni R, Zollo A, Bianchi C, Toniolo A. 2001. Properties of multidrug-resistant, ESBL-producing Proteus mirabilis isolates and possible role of $\beta$-lactam/ $\beta$-lactamase inhibitor combinations. International Journal of Antimicrobial Agents 17:131-135. DOI: 10.1016/s0924-8579(00)00325-3.

Mascher T. 2013. Signaling diversity and evolution of extracytoplasmic function (ECF) $\sigma$ factors. Current Opinion in Microbiology 16:148-155. DOI: 10.1016/j.mib.2013.02.001. 
596

597

598

599

600

601

602

603

604

605

606

607

608

609

610

611

612

613

614

615

616

617

618

619

620

621

622

623

624

625

626

627

628

629

630

631

632

633

634

635

Maszewska A, Zygmunt M, Grzejdziak I, Różalski A. 2018. Use of polyvalent bacteriophages to combat biofilm of Proteus mirabilis causing catheter-associated urinary tract infections. Journal of Applied Microbiology 125:1253-1265. DOI: 10.1111/jam.14026.

Milo S, Hathaway H, Nzakizwanayo J, Alves DR, Esteban PP, Jones BV, Jenkins ATA. 2017. Prevention of encrustation and blockage of urinary catheters by Proteus mirabilis via $\mathrm{pH}$ triggered release of bacteriophage. Journal of Materials Chemistry B 5:5403-5411. DOI: 10.1039/c7tb01302g.

Mirzaei MK, Mirzaei MK, Eriksson H, Kasuga K, Haggård-Ljungquist E, Nilsson AS. 2014. Genomic, proteomic, morphological, and phylogenetic analyses of vB_EcoP_SU10, a podoviridae phage with C3 morphology. PloS one 9:e116294. DOI: 10.1371/journal.pone.0116294.

Murphy J, Mahony J, Ainsworth S, Nauta A, Sinderen D van. 2013. Bacteriophage Orphan DNA Methyltransferases: Insights from Their Bacterial Origin, Function, and Occurrence. Applied and Environmental Microbiology 79:7547-7555. DOI: 10.1128/aem.02229-13.

Noguchi H, Taniguchi T, Itoh T. 2008. MetaGeneAnnotator: detecting species-specific patterns of ribosomal binding site for precise gene prediction in anonymous prokaryotic and phage genomes. DNA research : an international journal for rapid publication of reports on genes and genomes 15:387-396. DOI: 10.1093/dnares/dsn027.

O’Hara CM, Brenner FW, Miller JM. 2000. Classification, Identification, and Clinical Significance of Proteus, Providencia, and Morganella. Clinical Microbiology Reviews 13:534-546. DOI: 10.1128/cmr.13.4.534-546.2000.

Pearson MM, Sebaihia M, Churcher C, Quail MA, Seshasayee AS, Luscombe NM, Abdellah Z, Arrosmith C, Atkin B, Chillingworth T, Hauser H, Jagels K, Moule S, Mungall K, Norbertczak H, Rabbinowitsch E, Walker D, Whithead S, Thomson NR, Rather PN, Parkhill J, Mobley HLT. 2008. Complete Genome Sequence of Uropathogenic Proteus mirabilis, a Master of both Adherence and Motility $\nabla$ †. Journal of Bacteriology 190:4027-4037. DOI: 10.1128/jb.01981-07.

Pope WH, Anders KR, Baird M, Bowman CA, Boyle MM, Broussard GW, Chow T, Clase KL, Cooper S, Cornely KA, DeJong RJ, Delesalle VA, Deng L, Dunbar D, Edgington NP, Ferreira CM, Hafer KW, Hartzog GA, Hatherill JR, Hughes LE, Ipapo K, Krukonis GP, Meier CG, Monti DL, Olm MR, Page ST, Peebles CL, Rinehart CA, Rubin MR, Russell DA, Sanders ER, Schoer M, Shaffer CD, Wherley J, Vazquez E, Yuan H, Zhang D, Cresawn SG, Jacobs-Sera D, Hendrix RW, Hatfull GF, Imperiale MJ. 2014. Cluster M Mycobacteriophages Bongo, PegLeg, and Rey with Unusually Large Repertoires of tRNA Isotypes. Journal of Virology 88:2461-2480. DOI: 10.1128/jvi.03363-13.

Project I. n.d. Inkscape. Available at https://inkscape.org/.

Prozesky OW, Klerk HCD, Coetzee JN. 1965. The Morphology of Proteus Bacteriophages. Journal of General Microbiology 41:29-36. DOI: 10.1099/00221287-41-1-29.

Ramsey J, Rasche H, Maughmer C, Criscione A, Mijalis E, Liu M, Hu JC, Young R, Gill JJ. 2020. Galaxy and Apollo as a biologist-friendly interface for high-quality cooperative phage 
636

637

638

639

640

641

642

643

644

645

646

647

648

649

650

651

652

653

654

655

656

657

658

659

660

661

662

663

664

665

666

667

668

669

670

671

672

673

674

675

genome annotation. PLOS Computational Biology 16(11): e1008214. DOI:

10.1371/journal.pcbi.1008214.

Ren H, Li Z, Xu L, Li X, Wang L, Xu Y. 2019. Genome sequence analysis of Vibrio parahaemolyticus lytic phage Vp_R1 with a C3 morphotype. Archives of Virology 164:28652871. DOI: 10.1007/s00705-019-04364-0.

Satlin MJ, Chen L, Patel G, Gomez-Simmonds A, Weston G, Kim AC, Seo SK, Rosenthal ME, Sperber SJ, Jenkins SG, Hamula CL, Uhlemann A-C, Levi MH, Fries BC, Tang Y-W, Juretschko S, Rojtman AD, Hong T, Mathema B, Jacobs MR, Walsh TJ, Bonomo RA, Kreiswirth BN. 2017. Multicenter Clinical and Molecular Epidemiological Analysis of Bacteremia Due to Carbapenem-Resistant Enterobacteriaceae (CRE) in the CRE Epicenter of the United States. Antimicrobial agents and chemotherapy 61:1. DOI: 10.1128/aac.0234916.

Savalia D, Westblade LF, Goel M, Florens L, Kemp P, Akulenko N, Pavlova O, Padovan JC, Chait BT, Washburn MP, Ackermann H-W, Mushegian A, Gabisonia T, Molineux I, Severinov K. 2008. Genomic and proteomic analysis of phiEco32, a novel Escherichia coli bacteriophage. Journal of Molecular Biology 377:774-789. DOI:

10.1016/j.jmb.2007.12.077.

Sayers EW, Cavanaugh M, Clark K, Ostell J, Pruitt KD, Karsch-Mizrachi I. 2020. GenBank. Nucleic Acids Research 48:D84-D86. DOI: 10.1093/nar/gkz956.

Schaffer JN, Pearson MM. 2015. Proteus mirabilis and Urinary Tract Infections. Microbiology Spectrum 3. DOI: 10.1128/microbiolspec.uti-0017-2013.

Schoch CL, Ciufo S, Domrachev M, Hotton CL, Kannan S, Khovanskaya R, Leipe D, Mcveigh R, O’Neill K, Robbertse B, Sharma S, Soussov V, Sullivan JP, Sun L, Turner S, KarschMizrachi I. 2020. NCBI Taxonomy: a comprehensive update on curation, resources and tools. Database 2020. DOI: 10.1093/database/baaa062.

Sipley J, Stassi D, Dunn J, Goldman E. 1991. Analysis of bacteriophage T7 gene 10A and frameshifted 10B proteins. Gene expression 1:127-36.

Sullivan NL, Septer AN, Fields AT, Wenren LM, Gibbs KA. 2013. The Complete Genome Sequence of Proteus mirabilis Strain BB2000 Reveals Differences from the P. mirabilis Reference Strain. Genome Announcements 1:e00024-13. DOI: 10.1128/genomea.00024-13. Summer EJ. 2009. Preparation of a phage DNA fragment library for whole genome shotgun sequencing. Methods in molecular biology (Clifton, N.J.) 502:27-46. DOI: 10.1007/978-160327-565-1_4.

Tanaka N, Meineke B, Shuman S. 2011. RtcB, a Novel RNA Ligase, Can Catalyze tRNA Splicing and HAC1 mRNA Splicing in Vivo. Journal of Biological Chemistry 286:3025330257. DOI: 10.1074/jbc.c111.274597.

Thomas JA, Weintraub ST, Hakala K, Serwer P, Hardies SC. 2010. Proteome of the large Pseudomonas myovirus 201 phi 2-1: delineation of proteolytically processed virion proteins. Molecular \& cellular proteomics : MCP 9:940-951. DOI: 10.1074/mcp.m900488-mcp200. 
676 Tomás J, Regué M, Parés R, Jofre J, Kay WW. 1984. P1 bacteriophage and tellurite sensitivity

677

678

679

680

681

682

683

684

685

686

687

688

689

690

691

692

693

694

695

696

697

698

699

700

701

702

703

704

705

706

707

708

709

710

711

712 836. DOI: $10.1139 / \mathrm{m} 84-127$.

Turner D, Reynolds D, Seto D, Mahadevan P. 2013. CoreGenes3.5: a webserver for the determination of core genes from sets of viral and small bacterial genomes. BMC research notes 6:140. DOI: 10.1186/1756-0500-6-140.

Ujmajuridze A, Chanishvili N, Goderdzishvili M, Leitner L, Mehnert U, Chkhotua A, Kessler TM, Sybesma W. 2018. Adapted Bacteriophages for Treating Urinary Tract Infections. Frontiers in Microbiology 09:1832. DOI: 10.3389/fmicb.2018.01832.

Valentine RC, Shapire BM, Stadtman ER. 1968. Regulation of glutamine synthetase. XII. Electron microscopy of the enzyme from Escherichia coli. Biochemistry 7:2143-2152. DOI: 10.1021/bi00846a017;subpage:string:access.

Wang J-T, Chen P-C, Chang S-C, Shiau Y-R, Wang H-Y, Lai J-F, Huang I-W, Tan M-C, Lauderdale T-LY. 2014. Antimicrobial susceptibilities of Proteus mirabilis: a longitudinal nationwide study from the Taiwan surveillance of antimicrobial resistance (TSAR) program. BMC Infectious Diseases 14:486. DOI: 10.1186/1471-2334-14-486.

Weintraub ST, Redzuan NHM, Barton MK, Amin NAM, Desmond MI, Adams LE, Ali B, Pardo S, Molleur D, Wu W, Newcomb WW, Osier MV, Black LW, Steven AC, Thomas JA. 2018. Global Proteomic Profiling of Salmonella Infection by a Giant Phage. Journal of Virology 93. DOI: $10.1128 /$ jvi.01833-18.

Whelan KF, Colleran E, Taylor DE. 1995. Phage inhibition, colicin resistance, and tellurite resistance are encoded by a single cluster of genes on the IncHI2 plasmid R478. Journal of Bacteriology 177:5016-5027. DOI: 10.1128/jb.177.17.5016-5027.1995.

Young R. 2002. Bacteriophage holins: deadly diversity. Journal of molecular microbiology and biotechnology 4:21-36.

Zeng L, Skinner SO, Zong C, Sippy J, Feiss M, Golding I. 2010. Decision Making at a Subcellular Level Determines the Outcome of Bacteriophage Infection. Cell 141:682-691. DOI: $10.1016 /$ j.cell.2010.03.034.

Zimmermann L, Stephens A, Nam S-Z, Rau D, Kübler J, Lozajic M, Gabler F, Söding J, Lupas AN, Alva V. 2018. A Completely Reimplemented MPI Bioinformatics Toolkit with a New HHpred Server at its Core. Journal of Molecular Biology 430:2237-2243. DOI: 10.1016/j.jmb.2017.12.007.

Zulkower V, Rosser S. 2020. DNA Features Viewer: a sequence annotation formatting and plotting library for Python. Bioinformatics. DOI: 10.1093/bioinformatics/btaa213.

Peer) reviewing PDF | (2020:10:53564:1:0:NEW 25 Nov 2020) 


\section{Figure 1}

Privateer isolation and imaging

A) Privateer clear plaques with a diameter of $\sim 0.15-\mathrm{mm}$ on P. mirabilis ATCC 35659 lawn. B) The blue band containing the purified Privateer particles following $\mathrm{CsCl}$ step-gradient ultracentrifugation. C) Privateer transmission electron micrograph displaying virions $\sim 145 \times 35$ $\mathrm{nm}$, with a stubby $\sim 10-\mathrm{nm}$ tail.

A

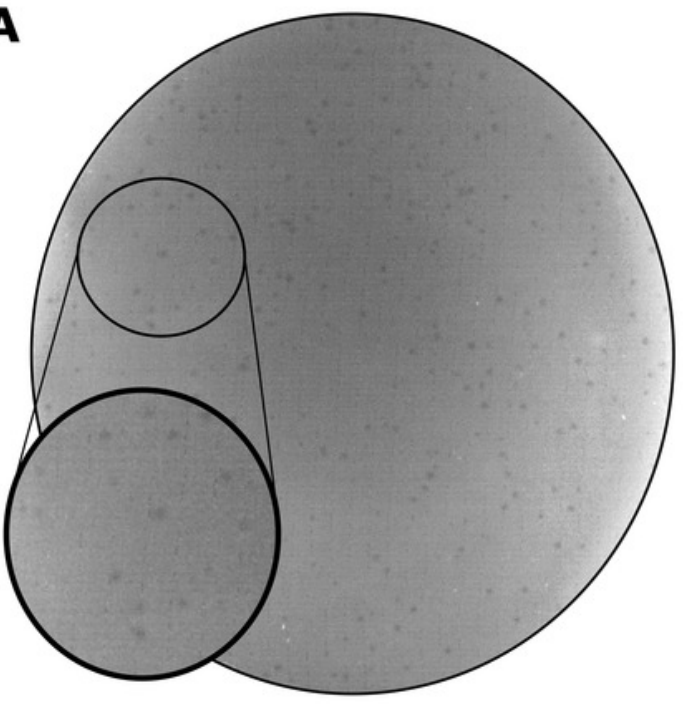

B

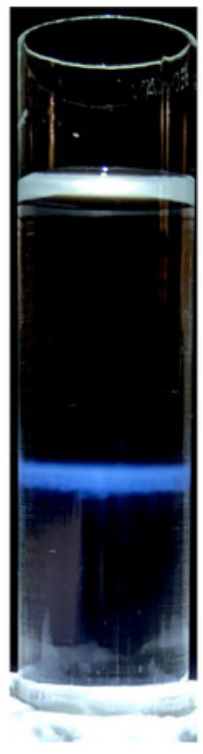

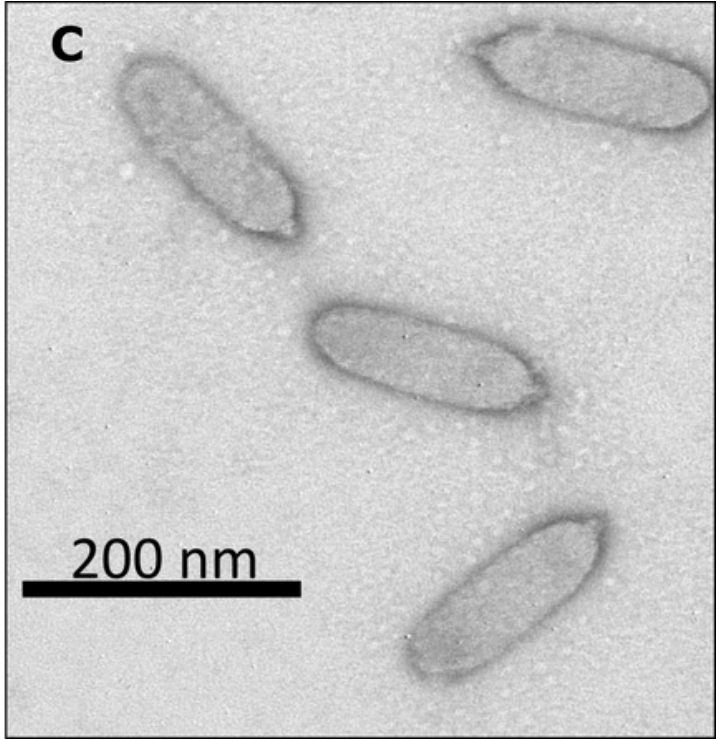


Figure 2

Characterization of Privateer infection.

A) Privateer adsorption curve, where phages not adsorbed to host cells were detected relative to input. $\mathrm{P} / \mathrm{Po}=$ free phages at time point $/$ free phages at 0 minutes. $\mathrm{B})$ Privateer one-step growth curve, where plaque-forming units were quantified after $\mathrm{MOI}=0.01$ infection. C) Lysis curve at $\mathrm{MOI}=10$, where $\mathrm{OD}_{550}$ of host liquid culture was measured over time. Representative instances of three replicates are shown. 
A

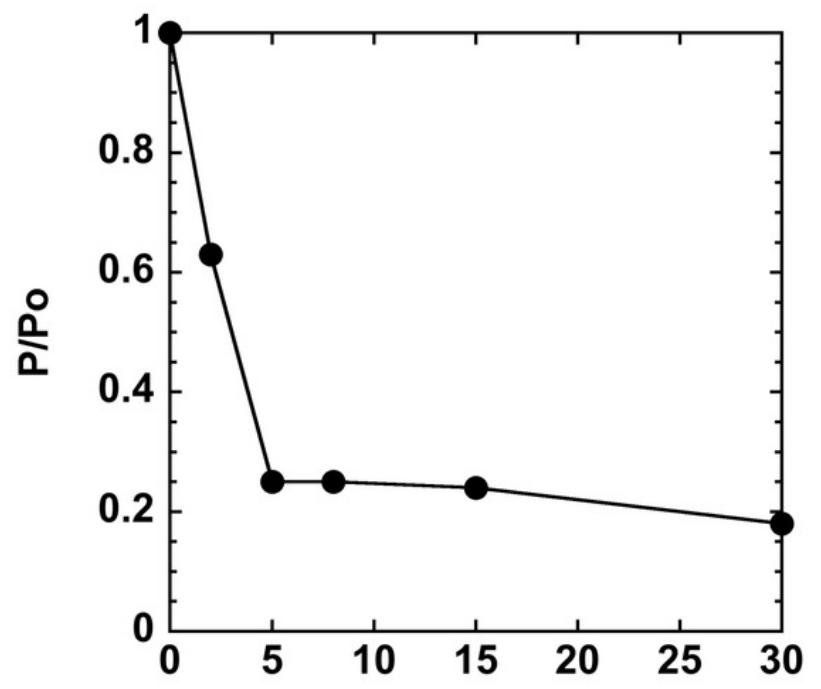

B
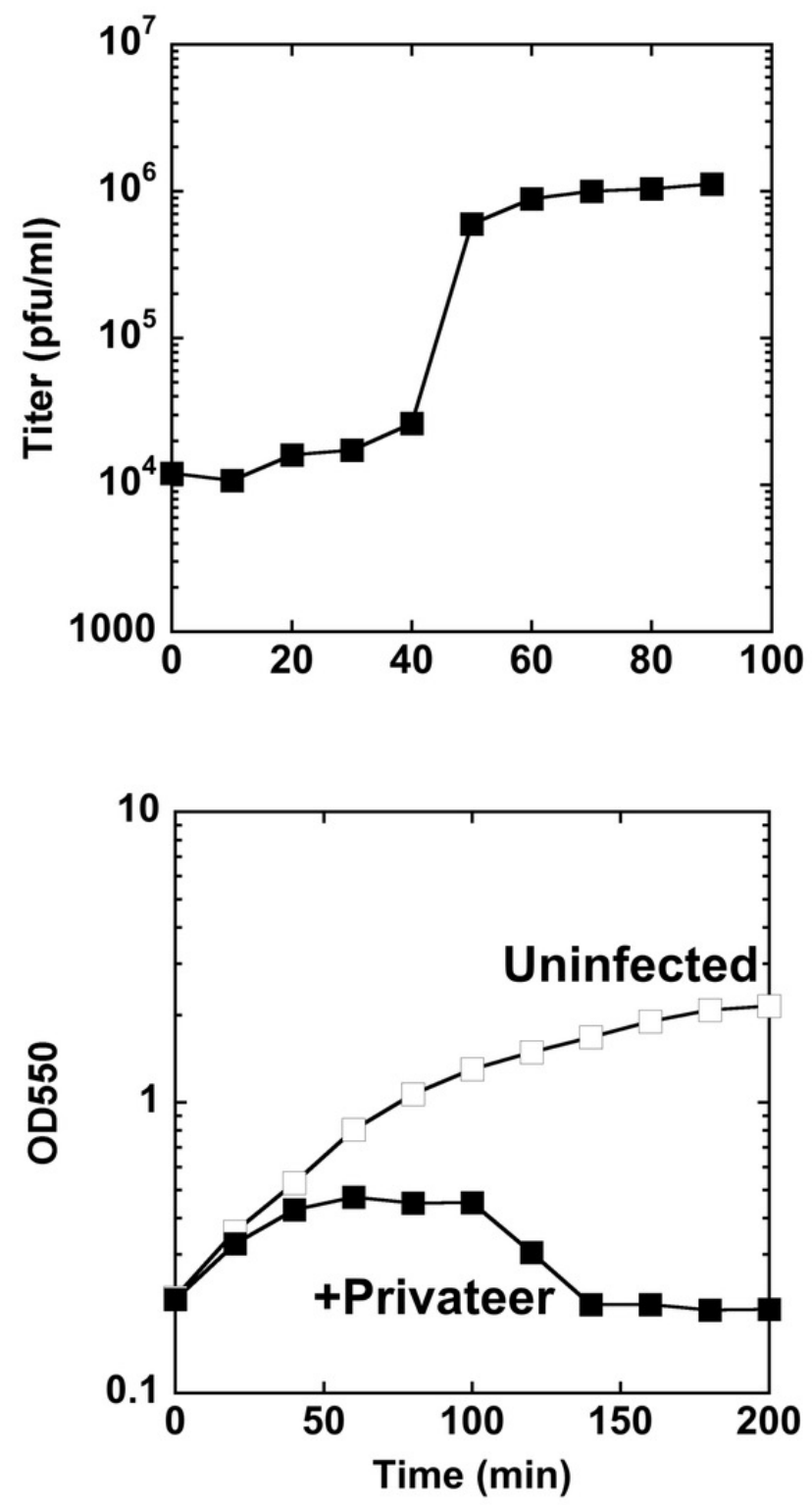

Peer] reviewing PDF | (2020:10:53564:1:0:NEW 25 Nov 2020) 
Figure 3

Privateer genome plot.

The predicted genes are color-coded corresponding to the functional categories of their protein products. The label for virion-associated proteins detected in purified phage particles by mass spectrometry are bordered with red.
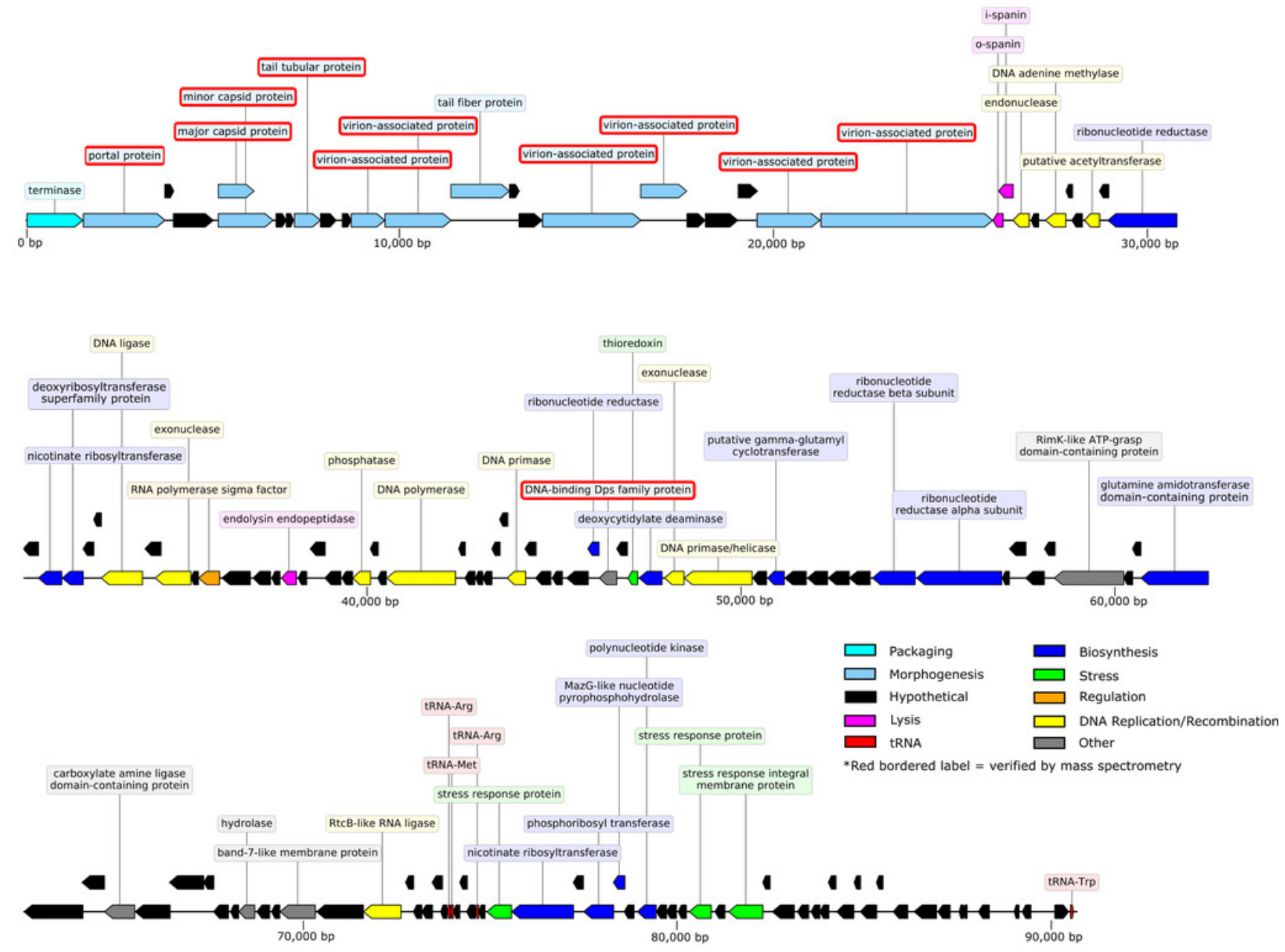


\section{Figure 4}

Comparative genomics among similar phiEco32-like phages.

Genome organization and comparison of protein identities for Proteus phage Privateer with selected C3 morphotype podophages. Cronobacter phage vB_CsaP_009 and Cronobacter phage VB_CsaP_GAP52 have the highest nucleotide identity with Privateer, and are all unclassified within the Podoviridae family. Escherichia phage Paul, Escherichia phage VB_EcoP_SU10, and Escherichia virus phiEco32 are phages in the Kuravirus genus. Proteins sharing significant sequence identity with at least $10^{-20}$ BLASTp expectation value are linked via gray bands (see Materials and Methods).

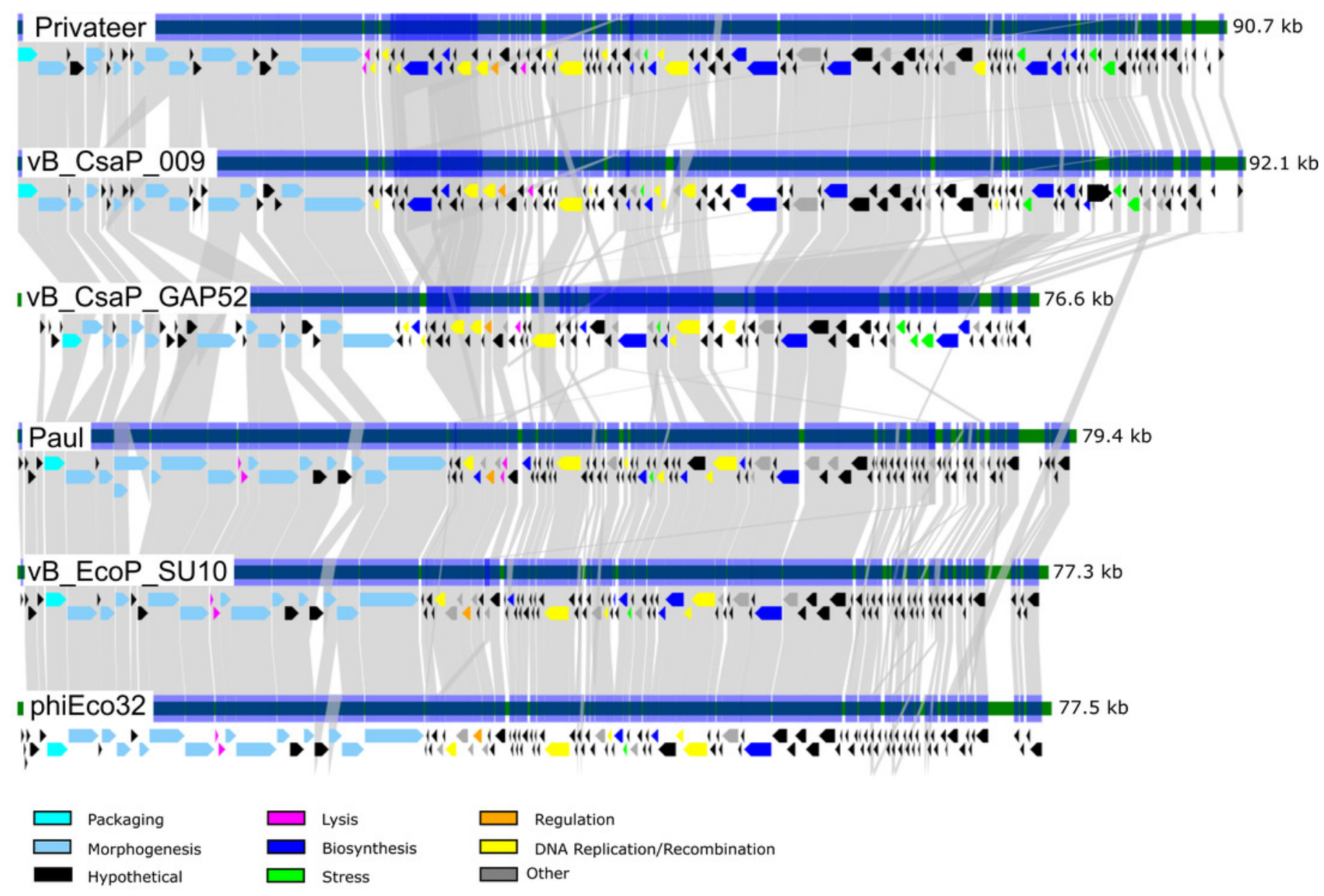




\section{Figure 5}

Analysis of Privateer virion proteins.

Proteins of phage Privateer identified by SDS-PAGE and mass spectrometry. A) CsCl purified phage particles were separated on a 4-20\% Tris-glycine SDS-PAGE gel. Molecular masses (in $\mathrm{kDa}$ ) of the protein ladder are displayed to the left of the gel. The white and black arrowheads indicate the expected location for minor and major capsid bands, respectively. B) Table of mass spectrometry results for trypsin-digested Privateer proteins from whole phage particles. The total spectrum count is equal to the total number of total peptide spectral matches assigned to the protein, and the unique peptide count is equal to the number of peptide sequences exclusive to the protein. C) Aligned sequences of the annotated major and minor capsid proteins. The highlighted regions indicate peptides identified via mass spectrometry. 
A

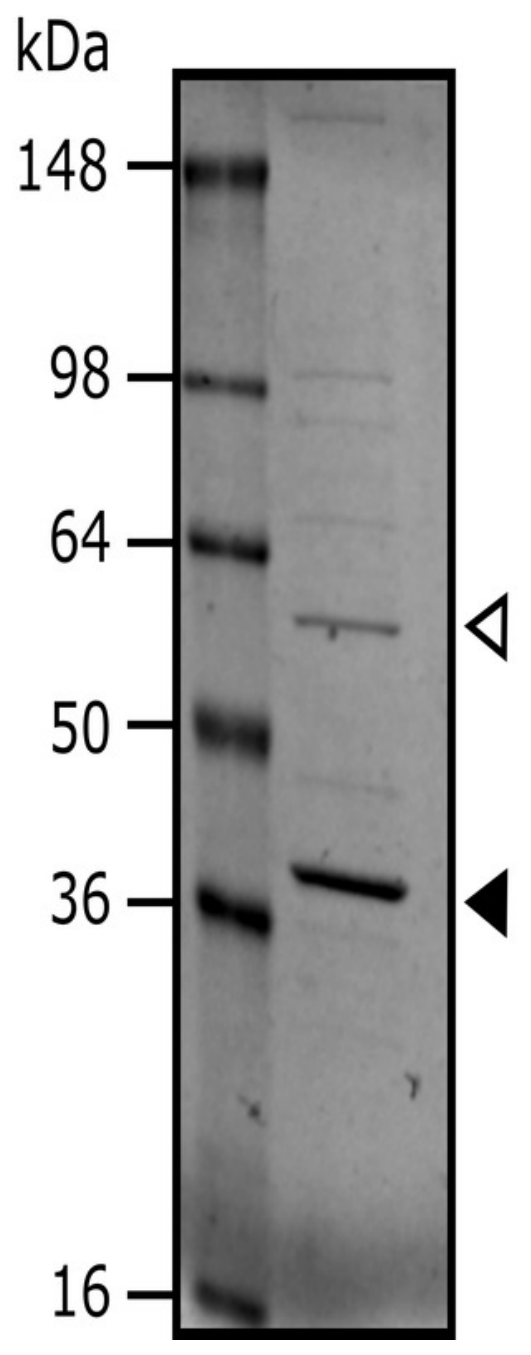

B

\begin{tabular}{l|c|c|c|c|c} 
Privateer Protein & $\begin{array}{c}\text { NCBI } \\
\text { Accession }\end{array}$ & $\begin{array}{c}\text { Calculated } \\
\text { Molecular } \\
\text { Weight }\end{array}$ & $\begin{array}{c}\text { Total } \\
\text { Spectrum } \\
\text { Count }\end{array}$ & $\begin{array}{c}\text { Unique } \\
\text { Peptide } \\
\text { Count }\end{array}$ & $\begin{array}{c}\text { \% } \\
\text { Coverage }\end{array}$ \\
\hline portal protein & QIN94795 & $83 \mathrm{kDa}$ & 4 & 4 & 6.3 \\
\hline $\begin{array}{l}\text { major/minor capsid protein } \\
\text { (identical prior to frameshift) }\end{array}$ & $\begin{array}{c}\text { QIN94798, } \\
\text { QIN94799 }\end{array}$ & $\begin{array}{c}35 \mathrm{kDa} \\
53 \mathrm{kDa}\end{array}$ & 132 & 54 & 63 \\
\hline tail tubular protein & QIN94802 & $27 \mathrm{kDa}$ & 2 & 2 & 13 \\
\hline virion-associated protein & QIN94805 & $33 \mathrm{kDa}$ & 3 & 3 & 14 \\
\hline virion-associated protein & QIN94806 & $68 \mathrm{kDa}$ & 2 & 2 & 4.3 \\
\hline virion-associated protein & QIN94810 & $97 \mathrm{kDa}$ & 6 & 5 & 7.8 \\
\hline virion-associated protein & QIN94811 & $43 \mathrm{kDa}$ & 5 & 4 & 10 \\
\hline virion-associated protein & QIN94815 & $61 \mathrm{kDa}$ & 8 & 6 & 14 \\
\hline virion-associated protein & QIN94816 & $169 \mathrm{kDa}$ & 8 & 8 & 7.8 \\
\hline DNA-binding Dps family protein & QIN94861 & $18 \mathrm{kDa}$ & 1 & 1 & 9.7
\end{tabular}

C

minor

1 MADNTLISYDLNGKKLSFANWISNLSPTETPFVSMTGKEAINQTLFQWQTDTLGQVDLNNAVAEGSPAED

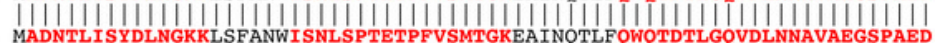

71 KERKSTTVLSNITQILRKVVKVSDTANALANYGRGKELQYOMEKAGKEIKRDLEAIFLNNGARVDGTGPG

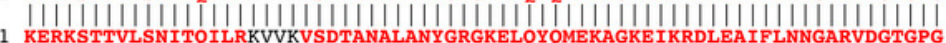

minor

141 LGDAGTARKTAGFKALVAAKDAADTDTGAVVHKEAELNEESLFDLTYNLYLSGSNANI IMFHPKHASFFA

major

minor

major

minor

major

minor

major

minor

major

minor

141 LGDAGTARKTAGFKALVAAKDAADTDTGAVVHKEAELNEESLFDLTYNLYLSGSNANI IMFHPKHASFFA

211 SLMETSAAGSNRMKMFDGPETRFKKYVSSIVDPLGQEYKLIPNRFMPQDAIYFFAPSDWTQMVLRAPQRT SLMETSAAGSNRMKMFDGPETRFKKYVSSIVDPLGOEYKLIPNRFMPQDAIYFFAPSDWTOMVLRAPORT

281 KLAKDGSYEKWMVEMEVGLRHRNPYASGILAVKAGEGK-

|||||||||||||||||||||||||||||||||||| $\mid$

281 KLAKDGSYEKWMVEMEVGLRHRNPYASGILAVKAGEGKVTSQPKDVTIEVGDSLTLSADADKYNSVOWFK

351

351 DDKEVSGATGTTYTKENVTLGDAGKYKAVFTGSYGKLETNTATVTVNEKTVEVESVELDTITAEVKIGET 421

421 IDLKATVKPDGATDKKLTWKSSDNKLATVTQTGKVKGVSEGEVKITATSSNGKSAEATVTVSKPDTE 487

Peptides identified in mass spectrometry analysis

Unique to minor capsid protein based upon translational frameshift 


\section{Figure 6}

Phylogenetic tree based on phage morphogenesis proteins.

The phylogenetic tree was built using four conserved structural proteins: portal, scaffold, major capsid, and tail tubular protein. Branch support values are displayed in red. See materials and methods for additional details and accessions.

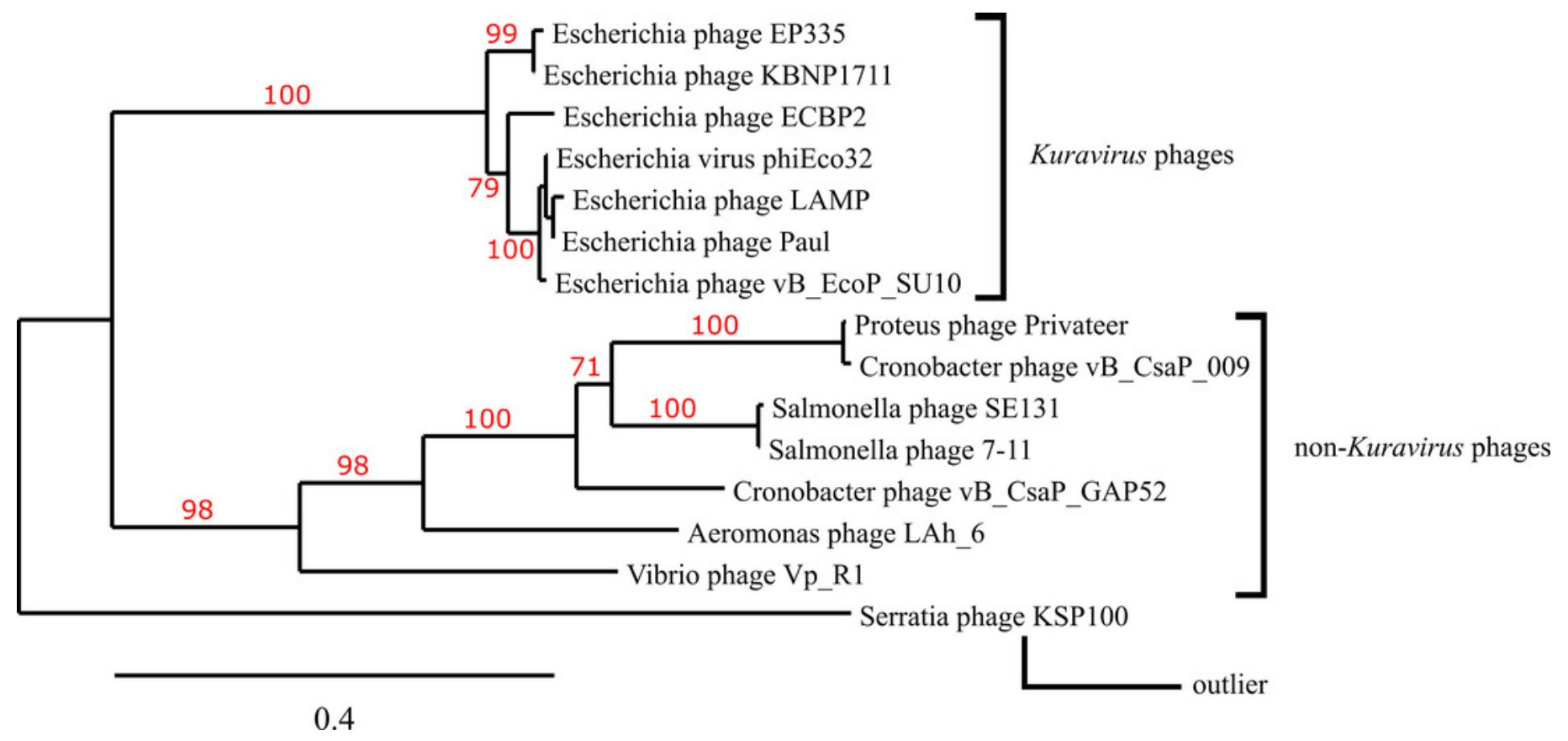




\section{Table $\mathbf{1}$ (on next page)}

Privateer host range among P. mirabilis strains and other Gammaproteobacteria

Proteus strains were considered sensitive if single plaques were observed at higher dilutions of the $10^{10} \mathrm{pfu} / \mathrm{mL}$ phage lysate. The bolded strain (ATCC 35659) indicates the host used for Privateer isolation. 
1

\begin{tabular}{|l|c|l|}
\hline Bacterial host & Sensitive to Privateer & \multicolumn{1}{c|}{ Description } \\
\hline P. mirabilis ATCC 35659 & + & Single plaques at $\geq \mathbf{1 0}^{2} \mathbf{p f u} / \mathbf{m L}$ \\
\hline$P$. mirabilis B446 & - & No clearing \\
\hline$P$. mirabilis ATCC 7002 & + & Single smaller plaques at $\geq 10^{6} \mathrm{pfu} / \mathrm{mL}$ \\
\hline$P$. mirabilis ATCC 29906 & + & Single smaller plaques at $\geq 10^{6} \mathrm{pfu} / \mathrm{mL}$ \\
\hline$P$. mirabilis ATCC 43701 & - & Faint clearing at $\geq 10^{9} \mathrm{pfu} / \mathrm{mL}$ \\
\hline$P$. mirabilis ATCC BAA-856 & + & Single smaller plaques at $\geq 10^{6} \mathrm{pfu} / \mathrm{mL}$ \\
\hline$P$. mirabilis ATCC 25933 & + & Single smaller plaques at $\geq 10^{6} \mathrm{pfu} / \mathrm{mL}$ \\
\hline$E$. coli MG1655 & - & No clearing \\
\hline$K$. pneumoniae $1776 \mathrm{c}$ & - & No clearing \\
\hline S. marcescens D1 & - & No clearing \\
\hline
\end{tabular}

2

3 Table 1 Privateer host range among $\boldsymbol{P}$. mirabilis strains and other Gammaproteobacteria.

4 Proteus strains were considered sensitive if single plaques were observed at higher dilutions of

5 the $10^{10} \mathrm{pfu} / \mathrm{mL}$ phage lysate. The bolded strain (ATCC 35659) indicates the host used for

6 Privateer isolation. 


\section{Table 2 (on next page)}

Comparative genomics phage accessions.

The hosts and Genbank accessions of the C3 podophages used for comparative genomics in this report. 
1

\begin{tabular}{|c|c|c|}
\hline Host & Podophage & Genbank Accession \\
\hline \multicolumn{3}{|c|}{ Kuravirus Phages } \\
\hline Escherichia coli & phiEco32 & EU330206 \\
\hline Escherichia coli & Paul & MN045231 \\
\hline Escherichia coli & vB_EcoP_SU10 & KM044272 \\
\hline Escherichia coli & KBNP1711 & KF981730 \\
\hline Escherichia coli & LAMP & MG673519 \\
\hline Escherichia coli & EP335 & MG748548 \\
\hline Escherichia coli & ECBP2 & JX415536 \\
\hline \multicolumn{3}{|c|}{ Non-Kuravirus Phages } \\
\hline Salmonella enterica & $7-11$ & HМ997019 \\
\hline Salmonella enterica & SE131 & MG873442 \\
\hline Cronobacter sakazakii & $\begin{array}{l}\text { vB_CsaP_GAP5 } \\
2\end{array}$ & JN882286 \\
\hline Cronobacter sakazakii & vB_CsaP_009 & LC519601 \\
\hline Aeromonas hydrophila & LAh_6 & MK838112 \\
\hline Vibrio parahaemolyticus & Vp_R1 & MG603697 \\
\hline Serratia marcescens & KSP100 & $\begin{array}{l}\text { AB452992 * only } \\
\text { contains structural } \\
\text { genes (orf1 to orf8) }\end{array}$ \\
\hline
\end{tabular}

3 Table 2 Comparative genomics phage accessions. The hosts and Genbank accessions of the $\mathrm{C} 3$ 4 podophages used for comparative genomics in this report. 